\title{
The Implementation of Norsok Z-008 for Equipment Criticality Analysis of Gas Central Processing Plant
}

\begin{abstract}
Dwi Priyanta ${ }^{1}$, Nurhadi Siswantoro ${ }^{2}$, Muhammad Badrus Zaman ${ }^{3}$, Dimas Fajar Prasetyo ${ }^{4}$
(Received: 04 February 2019 / Revised: 18 March 2019 / Accepted: 30 June 2019)

Abstract-The gas central processing plant as a facility used to process natural gas had a variety of components that were so complex and many in number. To reduce the risk of failure of these components it was necessary to carry out maintenance. But it would be very inefficient if all the components were treated at the same level, considering that there were so many and the human resources that were owned were very limited. Therefore, in taking care of these components it was necessary to prioritize them according to their critical level. In this research, in determining the critical level of a component using risk-based methods according to the available standards, namely NORSOK Z-008. By making a hierarchy and asset level register of all components, then the value of the probability rating and consequence rating was determined. So that the criticality ranking of each component was obtained according to the criticality risk matrix that was converted from the company's risk matrix, so that the critical level of the component was obtained in the levels of $H$ (high), $M$ (medium), and L (low). With the critical level of this component, the company did not need to take care of all the components. In this research, there was 33 equipment with 140 subunits/subsystems, and the total number of components was 674. Of the 674 components as many as 28 components had a critical level of $H$ (high), 192 components had a critical level M (medium), and 454 components had $L$ critical level (low) of each critical level that has been obtained, it is not necessary to carry out maintenance with the same level to all components. In this research, every component that has $H$ (high) criticality level will be treated as a Preventive Maintenance, while a component with a critical level of M (medium) will be Preventive Maintenance if needed, and a component with $L$ critical level (low) will be treated Corrective Maintenance.
\end{abstract}

\section{Keywords-Consequence, Equipment Criticality Analysis, Gas Central Processing Plant, Risk Ranking}

\section{INTRODUCTION}

$\mathrm{G}$ as processing consists of the separation of various types of hydrocarbons and fluids from pure natural gas. Before natural gas can be transported or delivered to consumers, the gas must be purified first. Natural gas must be separated from various contaminants and fluids such as crude oil (if any), and generally, there are other hydrocarbon mixtures such as ethane, propane, butane, and pentane. In addition, raw natural gas contains water vapor, hydrogen sulfide (H2S), carbon dioxide, helium, nitrogen, and other compounds. In the gas processing process, there are several processes including Manifold, separation, Gas Treatment, Compression, Gas Storage, Metering \& Export System, Utility System. [1]

Gas central processing plant as a facility used to process natural gas to become a gas that is ready to use has a variety of components that are so complex and many in number. In caring for these components is very inefficient if all components get attention and maintenance at the same level. Companies that have central processing plant gas facilities must have a sound strategy to be able to compete with other companies.

\footnotetext{
Dwi Priyanta, Department of Marine Engineering, Institut Teknologi Sepuluh Nopember, Surabaya 60111, Indonesia, Email: priyanta@its.ac.id

Nurhadi Siswantoro, Department of Marine Engineering, Institu Teknologi Sepuluh Nopember, Surabaya 60111, Indonesia, Email: nurhadi@ne.its.ac.id

Muhammad Badrus Zaman, Department of Marine Engineering, Institut Teknologi Sepuluh Nopember, Surabaya 60111, Indonesia, Email: drus_zaman@yahoo.com

Dimas Fajar Prasetyo, Department of Marine Engineering, Institut Teknologi Sepuluh Nopember, Surabaya 60111, Indonesia, Email: dimas.fajar.prasetyo15@mhs.ne.its.ac.id
}

One of them was in the strategy of caring for these components by using the Equipment Critical Analysis (ECA) method. Besides being used to analyze critical components, ECA is also used as a Screening tool in analyzing RBI according to DNV-RP-G101 standards [2].

Previous researchers who have examined the criticality of components were Rakesh Kumar Singh et al [3] showed the critical value of the components from the highest to the lowest with the AHP method. The results of the research found the highest critical level in the boiler component, and the lowest critical value was in the boiler feed pump. Other researchers were Fereshteh Jaderi et al [4] The research applied the AHP and Delphi Techniques method to analyze the critical sources at the plant. The conclusion of the research explains that critical analysis can help prioritize assets, improve maintenance management, reduce maintenance costs and increase production. Besides AHP method, FMECA method also familiar to be used in criticality analysis. FMECA is procedure to determine failure mode and classify potential failure effect according the severity, likelihood and detection [5-7] [14].

In application for petrochemical plants, a combination of criticality analysis used combination method HAZOP and FMECA had done by El-Arkam et.al [8]. FMECA also used to analyze criticality in liquefied natural gas fuel gas supply, however the methodology integrated the independency of axiomatic design and the hierarchical of FMECA [9]. Another method, using critical path software for project management can be used to determine risk register for critical activities [10]. In this research, the Norsok Z-008 is implemented to determine criticality for gas central processing. 


\section{METHOD}

A. Determine of Hierarchy, Main Function, Sub Function, and Redundancy

The purpose of determining the hierarchy of this system is to determine the scope of the system to be carried out by Equipment Critical Analysis (ECA), in this stage, the system will be divided into the main function, subfunction until it reaches the lowest level, in this research namely component.

TABLE 1

\begin{tabular}{ccccc}
\multicolumn{4}{c}{ EXAMPLE OF HIERARCHY TABLE OF GAS CENTRAL PROCESSING PLANT BASED ON ISO 14224 } \\
\hline Industry & $\begin{array}{c}\text { Business } \\
\text { Category }\end{array}$ & $\begin{array}{c}\text { Installation } \\
\text { Category }\end{array}$ & Plant/Unit & Section/System \\
\hline $\begin{array}{c}\text { Natural } \\
\text { Gas }\end{array}$ & Midstream & $\begin{array}{c}\text { Oil and gas } \\
\text { production }\end{array}$ & $\begin{array}{c}\text { Onshore } \\
\text { production } \\
\text { plant }\end{array}$ & Separation System \\
$\begin{array}{c}\text { Natural } \\
\text { Gas }\end{array}$ & Midstream & $\begin{array}{c}\text { Oil and gas } \\
\text { production }\end{array}$ & $\begin{array}{c}\text { Onshore } \\
\text { production } \\
\text { plant }\end{array}$ & $\begin{array}{c}\text { Dehidration } \\
\text { System }\end{array}$ \\
\hline
\end{tabular}

TABLE 2

EXAMPLE OF SYSTEM/SECTION CLASSIFICATION BASED ON ISO 14224

\begin{tabular}{cc}
\hline ID Asset & System/Section Classification \\
\hline 01 & Separation System \\
02 & Dehydration System \\
03 & Compression System \\
04 & Gas Export System \\
\hline
\end{tabular}

\section{B. Asset Register}

Data collection on each component in the object of analysis in accordance with its scope at the stage of determining the hierarchy for the future will be analyzed to determine the critical value.

\section{Determine the Probability Rating}

The failure rate (probability rating) of a component was identified and determined by knowing how an asset has failed. This failure rate was obtained based on the company's historical data and on the 2002 OREDA Handbook data bank [11]. Then it was categorized according to the Company Risk Matrix.

\section{Determine the Consequence Rating}

Each component had been classified according to hierarchy and the failure rate was determined, then an analysis of the risk was caused by the loss of the function of an asset based on a credible failure scenario.

\section{E. Determine the Equipment Criticality Analysis}

After determining the point of the probability of failure and consequences. in this research, in determining the criticality of components using riskbased methods according to the available standards, namely NORSOK Z-008 [12]. By prioritizing components based on their critical level into levels $\mathrm{H}$ (high), M (medium), and L (low).

\section{RESULT AND DISCUSSION}

\section{A. Collecting Data}

The data needed in conducting this research were all components in the gas central processing plant. This data is obtained by recording all the components in the $\mathrm{P}$ $\&$ ID image that are available. From these data the levels of Hierarchy, Main function, Subfunction, and Redundancy are determined.

\section{B. Hierarchy, Main function, Subfunction and Redundancy}

Hierarchy Determination by using ISO 14224 for the industry level to the section level was illustrated by the hierarchy of pyramid-shaped taxonomy with level 1 to level 9 [13]. Table 1 Showed examples of classification for hierarchy from Industry level (level 1) to Section/system level (level 5). Classifying according to this hierarchy can easily identify which component was in what scope or system. Table 2 showed an example of a section/system along with its Asset ID.

Determination of this hierarchy is done with the aim of knowing the level or level of a component in the hierarchy. Determination of Hierarchy is carried out using ISO 14224 and Norsok-Z-008 standards. According to ISO 14224, the hierarchy is divided into 9 levels. In this research, the gas central processing plant is at level 4. And the maintenance object in the form of components is limited to level 8. Table 3 showed the classification of Equipment for the determination of MF. Whereas Table 4 showed the classification of SF. 
TABLE 3

EXAMPLE OF EQUIPMENT CLASS/UNIT AND MAIN FUNCTION OF GAS CENTRAL PROCESSING PLANT

\begin{tabular}{ccc} 
ID Asset & Equipment Class/ Unit & Main Function \\
\hline 0101 & LP Separator & Separating \\
0206 & Glycol Regenerator & Regenerating \\
0301 & Gas Compressor & Compressing \\
\hline
\end{tabular}

TABLE 4

EXAMPLE OF SUB FUNCTION OF GAS CENTRAL PROCESSING PLANT

\begin{tabular}{ccc}
\hline ID Asset & Equipment Class/ Unit & Sub Function \\
\hline $0101 \mathrm{MT}$ & LP Separator & Main Task \\
$0101 \mathrm{CN}$ & LP Separator & Controlling \\
$0101 \mathrm{MN}$ & LP Separator & Monitoring \\
\hline
\end{tabular}

C. Determination of asset registers based on hierarchy

Determining the assets of the register was determined by giving a unique tag or number so that one asset with the other assets did not have an identical or the same name. For the asset list number code, the code is $\mathrm{XX}-\mathrm{YY}-\mathrm{ZZ}-\mathrm{EE}$, where:
1. $X X$
$=$ Section/System Number
2. YY= Equipment class/unit number
3. $\mathrm{ZZ}=$ Subunit/subfunction number
4. $\mathrm{EE}=$ Component

Table 5 showed a list of asset registers with the predetermined code to make it easier for workers to check or maintain on the field.

Based on the asset registers, it had been shown that the gas central processing plant has a total component of 674 components. From the total 674 components in 4 components in the form of rotary, as many as 19 components were static, 180 were piping, and 471 were instrument. Figure 1 showed a graph of the number of components present in the gas plant.

\section{Determine the Probability Rating}

Determination of probability rating was determined by describing a credible failure scenario for a component. After the failure scenario is described then the next is determining the failure mode. In this research determine the failure mode by using OREDA 2002. Determination of this failure mode will give a failure rate. Then from the failure rate, the MTBF value can be determined by dividing 1 per failure rate. Table 6 showed the failure mode and failure rate obtained from OREDA 2002. Then the value of this MTBF was classified according to the company's Risk Matrix. Table 7 showed the classification of Probability Ratings according to the company's Risk Matrix. Table 8 showed an example of a failure scenario and MTBF value of several components analyzed.

Therefore, the failure rate per year of LP Separator may become:

$$
\begin{aligned}
& \text { FR }_{\text {Lpseparator }}=\frac{\text { meand } f a \text { ilure a rate }}{10^{6}} \times 8760 \text { hours } \\
& \text { FR }_{\text {Lpseparator }} \quad=\frac{21.33}{10^{6}} \times 8760 \text { hours } \\
& \mathrm{FR}_{\text {Lpseparator } \quad=0.1869 \text { peryear }}
\end{aligned}
$$

The mean between failure (MTTF) may be calculated:

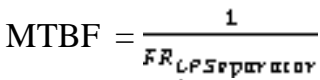

$$
\begin{aligned}
& \text { MTBF }=\frac{1}{0.1869} \\
& \mathrm{MTBF}=5.352 \text { years }
\end{aligned}
$$

\begin{tabular}{|c|c|c|c|}
\hline Component Tag & Component Name & SF & Equipment Class/Unit \\
\hline 0101MT-V-110B & LP Separator & Main Task & LP Separator \\
\hline 0101PR-PSV-110B & $\begin{array}{c}\text { Pressure Safety } \\
\text { Valve }\end{array}$ & $\begin{array}{l}\text { Pressure } \\
\text { Relief }\end{array}$ & LP Separator \\
\hline 0101CN-FSD-01 & Fire Shutdown & Controlling & LP Separator \\
\hline
\end{tabular}

TABLE 5

EXAMPLE OF ASSET REGISTER OF GAS CENTRAL PROCESSING PLANT 


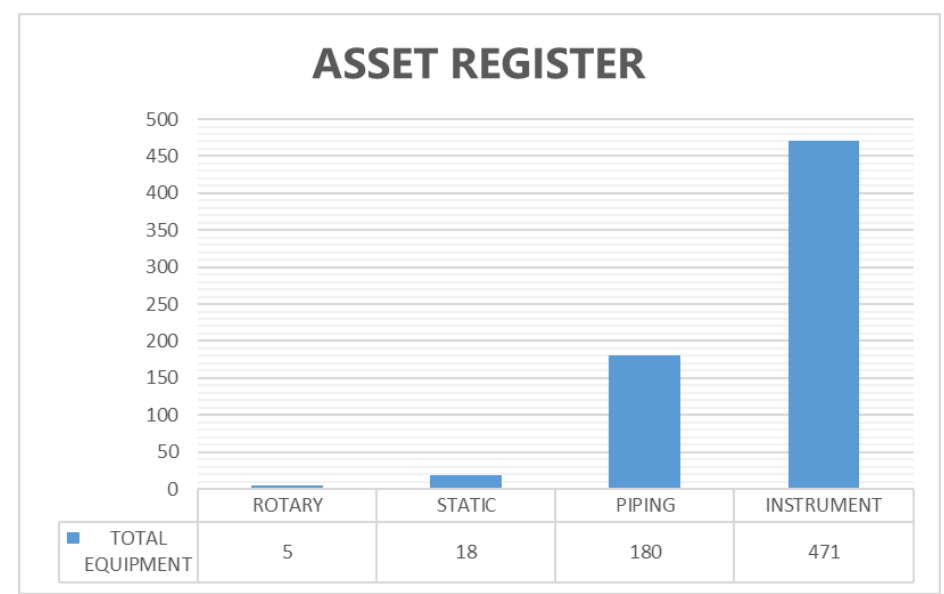

Figure 1. Total asset in gas central processing plant

TABLE 7

REDUNDANCY DEGREE BASED ON NORSOK Z-008 2011

\begin{tabular}{ccc}
\hline $\begin{array}{c}\text { Probability } \\
\text { Rating }\end{array}$ & Definition & Criteria \\
\hline 1 & Improbable & Less then Once per 15 years \\
2 & Unlikely Probable & Once per $>10-15$ years \\
3 & Probable & Once per $>5-10$ years \\
4 & Quite Probable & Once Per $>1-5$ years \\
5 & Very Probable & More than Once per year \\
\hline
\end{tabular}

TABLE 8

REDUNDANCY DEGREE BASED ON NORSOK Z-008

\begin{tabular}{|c|c|c|c|c|c|}
\hline $\begin{array}{c}\text { Component } \\
\text { Tag }\end{array}$ & $\begin{array}{l}\text { Component } \\
\text { Name }\end{array}$ & Failure Scenario & Failure Mode Selected & MTBF & $\begin{array}{c}\text { Probability } \\
\text { Rating }\end{array}$ \\
\hline $\begin{array}{l}0101 \mathrm{MT}-\mathrm{V}- \\
110 \mathrm{~B}\end{array}$ & $\begin{array}{c}\text { LP } \\
\text { SEPARATOR }\end{array}$ & $\begin{array}{l}\text { Unable to separating gas } \\
\text { from Fluid and another } \\
\text { Contaminant }\end{array}$ & $\begin{array}{c}\text { Abnormal instrument reading } \\
\text { External leakage - Process } \\
\text { medium } \\
\text { External leakage - Utility } \\
\text { medium }\end{array}$ & 5.352 & 3 \\
\hline $\begin{array}{l}\text { 0101PR-PSV- } \\
\text { 110B }\end{array}$ & $\begin{array}{l}\text { PRESSURE } \\
\text { SAFETY } \\
\text { VALVE }\end{array}$ & $\begin{array}{c}\text { Unable to provide } \\
\text { overpressure protection } \\
\text { for the LP Separator V- } \\
\text { 110B by relieving at } 600 \\
\text { psig for fire case }\end{array}$ & $\begin{array}{l}\text { Fail to open on demand } \\
\text { valve leakage in closed } \\
\text { position }\end{array}$ & 6.553 & 3 \\
\hline $\begin{array}{l}\text { 0101MS-2- } \\
\text { VLV-PG- } \\
103 \mathrm{~A}-6-3 \mathrm{~B}\end{array}$ & $\begin{array}{l}2 " \text { GLOBE } \\
\text { VALVE } \\
\text { MANUAL }\end{array}$ & $\begin{array}{c}\text { To control the fluid in } \\
\text { PG-103A-6-3B }\end{array}$ & $\begin{array}{c}\text { Delayed Operation: } \\
\text { open/closed below spec } \\
\text { Fail to close on demand: } \\
\text { stuck } \\
\text { Fail to open on demand: } \\
\text { stuck } \\
\text { External leakage - process } \\
\text { medium }\end{array}$ & 8.681 & 3 \\
\hline
\end{tabular}

\section{E. Determine Consequences}

To determine the risk score must have criteria in conducting an assessment. For the assessment criteria used in this paper were HS (Health, Safety) Production and Environment. In most industries, the risk matrix can be used to classify equipment to various levels of risk. When defining the consequences must have clear and easy definition criteria to communicate with others. The risk matrix criteria are:
- Risk matrix can be used for all types of equipment and can be used for all companies to assist operations.

- Risk matrix criteria must be for all equipment and systems.

The consequences for equipment are carried out by evaluating the potential impact of equipment failure. In this research, the Risk Matrix used a Risk Matrix from the Company. Based on Company Risk Matrix Table 9 
showed consequence classification of Health \& Safety. Table 10 shows the classification based on consequence
Environment. Table 11 showed the consequence classification based on Production.

TABLE 9

CONSEQUENCES CRITERIA OF HEALTH \& SAFETY BASED ON COMPANY RISK MATRIX

\begin{tabular}{ccc}
\hline $\begin{array}{c}\text { Consequence } \\
\text { Rating of HS }\end{array}$ & Definition & Criteria \\
\hline 1 & Very Low & Injury Without Treatment \\
2 & Low & Injury need Treatment with first aid Box \\
3 & Medium & Medical Treatment Without LTA \\
4 & High & Medical Treatment With LTA \\
5 & Very High & Fatality \\
\hline
\end{tabular}

TABLE 10

CONSEQUENCES CRITERIA OF ENVIRONMENT BASED ON COMPANY RISK MATRIX

\begin{tabular}{ccc}
\hline $\begin{array}{c}\text { Consequence } \\
\text { Rating of } \mathrm{E}\end{array}$ & Definition & Criteria \\
\hline 1 & Very Low & Have no nuisance effect at surround area \\
2 & Low & $\begin{array}{c}\text { Notable but limited environmental impact } \\
\text { Environmental impact notable lasting environmental } \\
\text { damage (Tier 1) }\end{array}$ \\
4 & High & $\begin{array}{c}\text { Large scale environmental damage with national } \\
\text { significance (Tier 2) }\end{array}$ \\
5 & Very High & $\begin{array}{c}\text { Severe widespread irreversible environmental damage of } \\
\text { international significance (Tier 3) }\end{array}$ \\
\hline
\end{tabular}

TABLE 11

CONSEQUENCES CRITERIA OF PRODUCTION BASED ON COMPANY RISK MATRIX

\begin{tabular}{ccc}
\hline $\begin{array}{c}\text { Consequence } \\
\text { Rating of } P\end{array}$ & Definition & Criteria \\
\hline 1 & Very Low & Gas leak (<0,5 MMSCFD) \\
2 & Low & Gas leak (0,5-<1 MMSCFD) \\
3 & Medium & Gas leak (1-<5 MMSCFD) \\
4 & High & Gas Leak (5-10 MMSCFD) \\
5 & Very High & Gas Leak (>10 MMSCFD) \\
\hline
\end{tabular}

\begin{tabular}{|c|c|c|c|c|c|c|}
\hline \multirow{2}{*}{\multicolumn{2}{|c|}{$\begin{array}{c}\text { RISK } \\
\text { MATRIX }\end{array}$}} & \multicolumn{5}{|c|}{ PROBABILITY RATING } \\
\hline & & \multirow{2}{*}{$\begin{array}{l}\mathbf{1} \\
1\end{array}$} & \multirow{2}{*}{$\begin{array}{l}2 \\
2\end{array}$} & \multirow{2}{*}{$\begin{array}{l}3 \\
3\end{array}$} & \multirow{2}{*}{$\begin{array}{l}4 \\
4\end{array}$} & \multirow{2}{*}{$\begin{array}{l}5 \\
5\end{array}$} \\
\hline$\underset{Z}{Z}$ & 1 & & & & & \\
\hline$₫$ & 2 & 2 & 4 & 6 & 8 & 10 \\
\hline$Z_{x}$ & 3 & 3 & 6 & 9 & 12 & 15 \\
\hline 8 & 4 & 4 & 8 & 12 & 16 & 20 \\
\hline 0 & 5 & 5 & 10 & 15 & 20 & 25 \\
\hline
\end{tabular}

Figure 2. Company risk matrix

TABLE 12

CRITICALITY CLASSES

\begin{tabular}{|c|c|c|c|}
\hline $\begin{array}{c}\text { Risk } \\
\text { Rating }\end{array}$ & Definition & Criticality Rating & Definition \\
\hline $1-5$ & Low & $\mathrm{L}$ & Low \\
\hline $5-9$ & Medium & M & Medium \\
\hline $\begin{array}{l}10-14 \\
15-25\end{array}$ & $\begin{array}{c}\text { Medium High } \\
\text { High }\end{array}$ & $\mathrm{H}$ & High \\
\hline
\end{tabular}




\begin{tabular}{|c|c|c|c|c|c|c|}
\hline \multirow{2}{*}{\multicolumn{2}{|c|}{$\begin{array}{l}\text { CRITICALITY } \\
\text { MATRIX }\end{array}$}} & \multicolumn{5}{|c|}{ PROBABILITY } \\
\hline & & \multirow{2}{*}{$\frac{1}{L}$} & \multirow{2}{*}{$\begin{array}{l}\mathbf{2} \\
\mathrm{L}\end{array}$} & \multirow{2}{*}{$\begin{array}{l}3 \\
\mathrm{~L}\end{array}$} & \multirow{2}{*}{$\begin{array}{c}4 \\
L\end{array}$} & \multirow[t]{2}{*}{5} \\
\hline \multirow{5}{*}{ 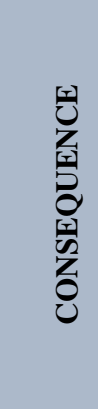 } & $\mathbf{1}$ & & & & & \\
\hline & 2 & $\mathrm{~L}$ & $\mathrm{~L}$ & M & $\mathrm{M}$ & $\mathrm{H}$ \\
\hline & 3 & $\mathrm{~L}$ & M & M & $\mathrm{H}$ & $\mathrm{H}$ \\
\hline & 4 & $\mathrm{~L}$ & M & $\mathrm{H}$ & $\mathrm{H}$ & $\mathrm{H}$ \\
\hline & 5 & M & $\mathrm{H}$ & $\mathrm{H}$ & $\mathrm{H}$ & $\mathrm{H}$ \\
\hline
\end{tabular}

Figure 3. Criticality risk matrix

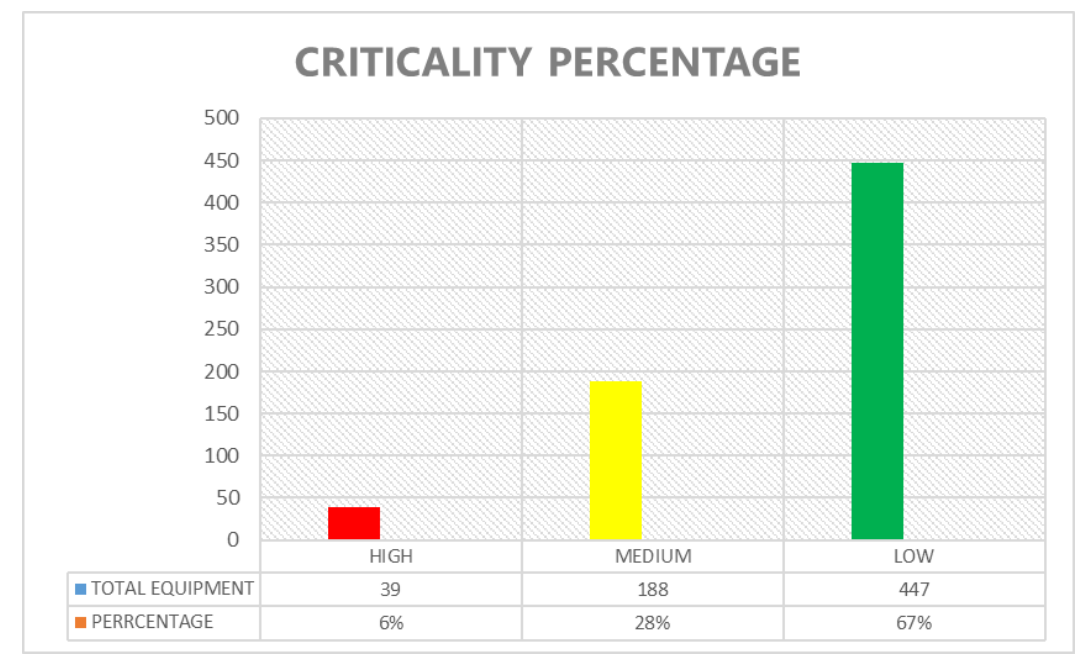

Figure 4. Diagram of equipment criticality analysis of gas central processing plant

\section{F. Determine the Equipment Criticality Analysis}

Criticality was the combination of stated likelihood and the consequence of potential function failure. The criticality of the component will be determined using a risk matrix from the company. The risk matrix of this company will be converted into 3 classifications, namely $\mathrm{H}$ (high), $\mathrm{M}$ (Medium), L (low). Figure 2 showed the Company Risk Matrix. Table 10 showed the conversion of the company risk matrix into the critical component matrix. Figure 3 showed a picture of the component criticality matrix.

\section{G. Result}

After determining the probability rating dan failure consequences rating, the next step was determining the equipment classification or scoring the equipment of gas central processing plant. Based on the result by determining the equipment classification based on level critical the following result are obtained:

- 28 equipment high risk $(4 \%)$

- 192 equipment medium risk (28\%)

- 454 equipment low risk level (67\%)

Figure 4 showed a critical graph of the component based on the levels of $\mathrm{H}$ (High), M (Medium), L (Low).

\section{CONCLUSION}

In this research used Equipment Criticality Analysis method in the causal analysis as well as determining the risk level of each equipment of gas central processing plant. Based on the application of ECA of gas central processing plant:

1. Hierarchy based on the combination of ISO 14224 and Norsok Z-008 2011 on this research divided into:

- Industry: natural gas

- Business Category: midstream

- Installation Category: Oil/gas production

- Plant/Unit Category: Onshore Plant

- Section/System: 9 system

- Equipment Class/Unit: 33 Equipment

- Subunit/Subfunction: 140 Subunit

- Component: 647 components

Having a well-defined asset taxonomy may help the superintendent work easily. Also known the boundaries of plant and equipment.

2. Based on criticality risk level equipment there were 3 levels low, medium, and high level. For Equipment Gas Central Processing Plant are 28 equipment High risk level (4\%). 192 equipment 
medium risk level (28\%), and 454 equipment low risk level (67\%).

3. Every critical level has different maintenance strategy. Low level must be corrective maintenance, medium level must be preventive maintenance if appropriate, and high level must be preventive maintenance because if the high-level risk equipment did not get preventive maintenance may interrupt the business for company, dangerous for crew, and dangerous for environmental.

\section{REFERENCES}

[1] H. Devold, "Oil and Gas Production Handbook An Introduction to Oil and Gas Production, Transport, Refining and Petrochemical Industry," USA: Etterstad, 2013.

[2] Priyanta, Dwi, "The Development of equipment criticality analysis (ECA) protocols of offshore carbon steel static mechanical equipment," Asian Journal of Applied Sciences, Vol.4(6), pp. 1258-1266, Dec. 2016.

[3] Singh,Rakesh Kumar; Kulkani and Makarand S., "Criticality analysis of power-plant equipment using the analytic hierarchy process," International Journal of Industrial Engineering \& Technology (IJIET), Vol.3, pp. 1-14, 2013.

[4] Fereshteh J., ELham S., Bagher A. and Nader N., "Criticality analysis for assets priority setting of abadan oil refinery using AHP and Delphi Techniques," International Journal of Engineering and Innovative Technology(IJEIT), Vol. 2(6), pp. 48-53, Dec. 2012

[5] Sutrisno, Agung; Gunawan, Indra and Tangkuman Stenly, "Modified failure mode and effect analysis (FMEA) model for accessing the risk of maintenance waste," Procedia Manufacturing, Vol.(4), pp. 23-29, 2015.

[6] Roghanian, Emad; Mojibian, Fatemeh, "Using fuzzy FMEA and fuzzy logic in project risk management," Iranian Journal of Management Studies (IJMS), vol. 8(3), pp. 373-395, July 2015.

[7] Chin, Kwai-Sang; Chan, Allen and Yang, Jian-Bo, "Development of a fuzzy FMEA based product design system," Internaionlal Journal Advanced Manufacture Technology, vol.(36), pp. 633-649, 2008.
[8] Mechhoud, El-Arkam; Mounira, Rouainia and Rodriguez, Manuel, "A New Tool for Risk Analysis and Assessment in Petrochemical Plants," Alexandria Engineering Journal, Vol.55, pp. 2919-2931, 2016.

[9] Goo, Bongeun; Lee, Joohee; Seo, Suwon; Chang, Daejun and Chung, Hyun, "Design of reliability critical system using axiomatic design with FMECA," International Journal of Naval Architecture and Ocean Engineering, pp. 1-11, 2017.

[10] Zaman, M. Badrus; Siswantoro, Nurhadi and Nandiansyah, Rizky R., Semin, "Risk Assessment in ship repair scheduling," International Journal of Mechanical Engineering and Technology (IJMET), vol.10(3), pp. 1-8, Mar. 2109.

[11] OREDA Participants, "OREDA - Offshore Reliability Data Hanbook 4th edition," Norway: OREDA companies, 2002.

[12] Standards Norway, "Risk based maintenance and consequence classification - Norsok Z-008 3rd edition," Norway: Norsok Standard, 2011.

[13] BSI Standards Publication, "Petroleum, petrochemical and natural gas industries - Collection and exchange of reliability and maintenance data for equipment (ISO 14224:2016)," UK: BSI Standards Ltd, 2016

[14] Rahmadhnty, Shaneza Fatma; Pitana, Trika and Siswantoro, Nurhadi, "Reviewing the RCM on cooling water pump of LNG production company," International Journal of Marine Engineering Innovation and Research, Vol.3(3), pp. 109-117, Mar. 2019. 